\title{
3 National language policy theory: exploring Spolsky's 4 model in the case of Iceland
}

Abstract Language policies are born amidst the complex interplay of social, cultural, religious and political forces. With this in mind, Bernard Spolsky theorises that the language policy of any independent nation is driven, at its core, by four cooccurring conditions-national ideology, English in the globalisation process, a nation's attendant sociolinguistic situation, and the internationally growing interest in the linguistic rights of minorities. He calls for this theory to be tested (Spolsky in Language policy, Cambridge University Press, Cambridge, 2004). This paper accepts the invitation by firstly considering the contributions and limitations of Spolsky's theory vis-à-vis other contemporary research approaches and then applies the theory to the case of Iceland. Iceland is a dynamic locus for this purpose, given its remarkable monodialectism, fervent linguistic purism and protectionism, and history of overwhelming homogeneity. The study finds that all Spolsky's factors have in some way driven Icelandic language policy, except in issues of linguistic minority rights. Instead, Icelandic language policy discourse reveals a self-reflexive interest in minority rights whereby Icelandic is discursively positioned as needing protection in the global language ecology. Accordingly, the paper examines how Spolsky's theory may be refined to account for non-rights-based approaches to national language policies.

Keywords Language policy theory $\cdot$ Spolsky $\cdot$ Linguistic rights $\cdot$ Relative minority $\cdot$ Linguistic protectionism

\section{Introduction}

Language policy research invites perspectives from across social sciences because a nation's language policy is born from the unique interplay of its political, cultural,

A2 Center for Multilingualism in Society Across the Lifespan, University of Oslo, Oslo, Norway

\begin{tabular}{|l|lllll|}
\hline & Journal : Small-ext 10993 & Dispatch : $\mathbf{2 0 - 2 - 2 0 1 5}$ & Pages : 18 \\
Article No. : 9357 & $\square$ LE & & $\square$ & TYPESET \\
& MS Code : LPOL-537 & $\square$ CP & DISK \\
\hline
\end{tabular}


religious, educational and economic ambitions and realities (Spolsky and Shohamy 2000). An accurately nuanced understanding of any nation's language policy calls, therefore, for contextualised perspectives. However, in considering the genesis of language policy, Spolsky (2004) proposes that motivations behind the language policies of modern independent nation states can be categorised by four fundamental and co-existing factors: national ideology, the role of English as a global language, a nation's sociolinguistic situation, and an increasing interest in the rights of linguistic minorities. Spolsky (2004) himself proposes that 'this theoretical model needs to be tested against actual cases' (p. 133).

Iceland is a tempting case for this purpose, given its extraordinary linguistic history. Specifically, both ancient and modern language matters are pertinent to current language policy in this internationally small but vivacious language community. The Icelandic community itself has remained passionately engaged in the politics and planning of its language since Norwegian settlement between 870 and 930 (Árnason 2003), and ideologies of linguistic purism have been sustained. This has nuanced Iceland's social and political history, because the perceived purity of Icelandic as the proto-Scandinavian language-hand in hand with Iceland's medieval literature-has helped to shape modern Icelandic identities. Today, language policy discourse is still intrinsic to contemporary Iceland, but now it exists against a backdrop of expanding fractures in Iceland's linguistic homogeneity. Spolsky (2004) has previously referred to Iceland, but his discussions illustrated Iceland as a purist polity or a phenomenal example of what was perhaps a truly monolingual nation. Given Spolsky has tagged the language community as exceptional, Iceland has been intensely concerned with linguistic protectionism, and its sociolinguistic landscape has just begun to truly transition to linguistic diversity, Iceland is a challenging case for critically testing Spolsky's theory.

The theory may seem at odds with the current age in language policy scholarship that subscribes to the language policy onion with its focus on the many interacting agents, levels and processes of language policy (Ricento and Hornberger 1996). Indeed, Spolsky's theory does not claim to entertain the critical perspectives the onion model can facilitate but instead focuses on language policy at the nation-state level. This paper seeks to position Spolsky's theory in the broader language policy research field and consider its contributions and weaknesses within the case of Iceland.

\section{Spolsky's theory}

Spolsky (2009: 1) proposes that language policies at the national level are driven by four common and co-existing forces:

- national (or ethnic) ideology or claims of identity;

- the role of English as a global language;

- a nation's sociolinguistic situation; and

- an increasing interest in linguistic rights within the human and civil rights framework. 
National ideology and identity refer to the infrastructure of beliefs and principles relevant to a collective psyche that may manifest in language policy. For illustration, Spolsky reflects on northern African nations where post-colonial Arabisation instituted Arabic as an official language on the primacy of the Qur'an in national and cultural identity (Spolsky 2004).

The role of English refers to what Spolsky (2004) calls the 'tidal wave of English that is moving into almost every sociolinguistic repertoire' (p. 220) throughout the global language ecology. As the language of global communication, English has come to index a cosmopolitan social and economic mobility. For example, as a language polity, the Netherlands emphatically prioritises English as a second language (L2) (Ytsma 2000: 228). However, the wave can also create tensions between linguistic internationalisation and local language interests (May 2014), meaning the tidal wave may also be resisted by way of interventions to protect the status or vitality of local languages. For example, discourse in Germany reveals a simmering worry about English and debates ensue about the marginalisation of German (Phillipson 2003: 80).

The sociolinguistic situation refers to 'the number and kinds of languages, the number and kinds of speakers of each, the communicative value of each language both inside and outside the community being studied' (Spolsky 2004: 219). This is not just concerned with the factual sociolinguistic setting, but also with subjective perceptions about the importance of specific languages. However, it is important in language policy research not to accept any sociolinguistic situation prima facie because sociolinguistic arrangements may not be 'inevitable or logical, but rather the result of political processes and ideologies of state formation' (Ricento 2006: 15). This is not to undo this component of Spolsky's theory but rather to highlight its interconnectedness with his three other components, as well as the salience of examining language ideologies in language policy, given perceived and real sociolinguistic situations may be manifestations of socio-political arrangements and ideologies.

The final factor, Spolsky (2004) claims, is the increasing global interest in 'linguistic pluralism and an acceptance of the need to recognize the rights of individuals and groups to continue to use their own languages' (p. 220). Spolsky (2005) especially recalls the international awareness of minority issues sparked by the American civil rights movement and twentieth century international human rights instruments that affirm and protect language minorities either explicitly or implicitly. Language is positioned as an element of human rights, urging nations to offer language rights to their minorities in some way, such as provisions for minority language-medium schooling (Spolsky 2004). This is indeed the case, for example, for speakers of Maori in New Zealand (May and Hill 2005) and French Canadians outside Quebec (May 2014). Spolsky's final component therefore sees nations as necessarily interested in developing and implementing permissive language rights for their minorities.

\section{Spolsky's theory in contemporary language policy scholarship}

Spolsky's four factors constitute a theory on what informs national language policy. While Spolsky (2004) does not label these essential forces, he claims that 'language

\begin{tabular}{lllll} 
Journal : Small-ext 10993 & Dispatch : & $\mathbf{2 0 - 2 - 2 0 1 5}$ & \multicolumn{2}{l}{ Pages : 18 } \\
Article No. $: \mathbf{9 3 5 7}$ & $\square \quad$ LE & $\square$ & TYPESET \\
MS Code : $\quad$ LPOL-537 & $\square$ & CP & $\square$ & DISK \\
\hline
\end{tabular}


policy for any independent nation state will reveal the complex interplay of (these) four interdependent but often conflicting factors' (p. 133). The forces may overlap and be interconnected depending on local context and policy realisation, but are nonetheless deemed identifiable as the core motivations.

However, in an era in sociolinguistic research that emphasises post-structuralist and localised observations of language, a national language policy theory is not without challenges. Indeed, the field has accepted that language policy is much more than official policy alone because the real language policy situation of a community is realised via the multitude of actors, contexts, processes, interpretations, negations and contestations of official policy directives. Accordingly, the ethnography of language policy seeks to replace bureaucracy-oriented research of language policy with bottom-up perspectives that examine community-level engagements with language as a policy phenomenon (Johnson 2013) and illustrate the real-life repercussions of policy. Through ethnography the field can engage policy on the ground in order to 'offer a balance between policy power and interpretive agency' and be 'committed to issues of social justice' (Johnson and Ricento 2013: 15), rather than limiting studies to official discourses. A theory such as Spolsky's does not seem equipped to offer that critical grass-roots perspective.

Postmodernism has also extended our focus to observing community-level governance structures that inform how languages are managed (Pennycook 2006). Indeed, Pennycook (2013) argues that communities' ideologies may be so influential that they regulate language in society beyond official policy. This was indeed the case in Zavala's (2014) research of official Quechua policy where policy objectives are at odds with ideologies of Quechua acquisition. This echoes the contributions to Menken and García (2010) edited book that examine the pertinent role of educators as regulators of language beyond the sphere of governments. Theorising on language policy also assumes a universal understanding of what languages in fact are, and how they can de identified and delineated. Pennycook (2002) presents concerns about the notion of mother tongue, and the sociolinguistic attributes attached to it, as it informs policy. The superdiverse milieu of many communities worldwide has instead drawn attention to the notion of languaging: citizens of linguistically diverse communities may sooner 'employ whatever linguistic features are at their disposal with the intention of achieving their communicative aims' (Jørgensen 2008: 169) than adhere to traditional notions of mother tongue that a universal language policy theory might rely on. Furthermore, European conceptualisations of language and language vitality that tend to steer policy are indeed just European. In the case of the native American Hopi community, for example, the benevolent ambitions of linguists to teach the language in the public sphere and create dictionaries in fact breached Hopi protocols because traditional beliefs are that documenting and exposing the language to outsiders would 'fix the sounds and meanings of the Hopi language in an alien, objectified form' (Whiteley 2003: 717).

A postmodernist perspective would add that any theory that constitutes a grand narrative should be rejected because it naively seeks to explain language in society universally without regard to local policy contexts. This is reminiscent of Schiffman's view that the real language policy of any given community comprises

\begin{tabular}{|l|lllll|}
\hline & Journal : Small-ext 10993 & Dispatch : & $\mathbf{2 0 - 2 - 2 0 1 5}$ & Pages : 18 \\
Article No. : $\mathbf{9 3 5 7}$ & $\square \quad$ LE & $\square$ & TYPESET \\
& MS Code : LPOL-537 & $\square \quad C P$ & $\square$ & DISK \\
\hline
\end{tabular}


overt de jure and covert de facto policies, both of which arise from a community's unique linguistic culture. Whereas overt policies are created and implemented by authorities, covert policies are the unwritten sociolinguistic patterns that in effect operate like policy. Overt and covert policies, therefore, cannot be theorised universally as they arise from a single community's 'ideas, values, beliefs, attitudes, prejudices, myths, religious strictures, and all other cultural "baggage" that speakers bring to their dealings with language from their culture' (Schiffman 2006: 112). Shohamy (2006) offers similar discussion when she calls for an expanded view of language policy to give weight to the covert mechanisms and ideologies that guide language behaviour. As she argues, it may be the case that 'even the most declared multilingual policies do not always reflect the de facto and real (language policies), as these provide only lip service, declarations and intentions' (Shohamy 2006: 52).

With these challenges in mind, language policy research has commonly avoided grand theorising and has often become localised and domain-centred (Ricento 2006). This is Ricento's preference, because in his view 'there is no overarching theory of (language policy) and planning, in large part because of the complexity of issues which involve language in society' (2006: 10). However, Spolsky's attempt at identifying the four core motivations behind language policy does not claim to be an all-encompassing theory, as it is well-established that language policy is not just made by government authorities but also community groups, schools, and families. It also does not claim to provide the critical interpretive and agency perspectives that multi-layered approaches to language policy explore.

Spolsky's theorising, as already stated, concerns language policies of independent nations as a topic of scholarship in itself. Indeed, I would argue that the growing interest in community-level perspectives of language policy does not erase the need to understand what drives governments to create the language policies they do. Instead, it only strengthens this need, as this can only support and better contextualise any grassroots research that is positioned vis-à-vis national language policy frameworks in order to explore the repercussions of policy. Understanding what drives governments to create certain policies can only help to understand, for example, the origin of the hegemonies and of state-sanctioned language ideologies that communities may ultimately experience and respond to.

\section{Research methodology and theoretical foundation}

This study took each of Spolsky's four factors and analysed their relevance to current Icelandic language policy so as to arrive at a conclusion as to whether, and if so, how, these factors have motivated Iceland's language policy. A qualitative approach was taken by reviewing primary and secondary literature about the language and language policy situation in Iceland, including books, book chapters, journal articles, theses and unpublished literature. Particular attention was given to discussions by prominent scholars of Icelandic language policy and Icelandic sociolinguistics generally, including Árnason (2003), Arnbjörnsdóttir (2007, 2010, 2011), Hálfdanarson (2003, 2005), Hilmarsson-Dunn (2003, 2006, 2009, 2010),

\begin{tabular}{|l|llll|}
\hline & Journal : Small-ext 10993 & Dispatch : $\mathbf{2 0 - 2 - 2 0 1 5}$ & Pages : 18 \\
Article No. : $\mathbf{9 3 5 7}$ & $\square \quad$ LE & $\square$ & TYPESET \\
& MS Code : LPOL-537 & $\square$ CP & $\square$ & DISK \\
\hline
\end{tabular}


Hilmarsson-Dunn and Kristinsson (2009), Kristinsson (2012), Kvaran (2003, 2004, 2010), Rögnvaldsson (2008) and Svavarsdóttir (2008), and especially HilmarssonDunn and Kristinsson (2010) with their comprehensive monographs of language in Iceland. The research also drew on primary sources that provided direct insights to, and evidence of Iceland's language policy, including government and governmentfunded websites (e.g., Alpingi, ${ }^{1}$ the Ministry of Science, Education and Culture, the Ministry of the Interior, and the Árni Magnússon Institute for Icelandic Studies), and news media with stories, editorials and opinions relevant to language policy discourse. Although the research was limited to sources available in English, scholarship in Icelandic sociolinguistics and Icelandic language policy information is commonly available in English.

Given the research evaluated the relevance of Spolsky's theory regarding the factors that motivate language policy, it was only fair to his scholarship that the study also applied his conceptualisation of what language policy actually comprises. Presumably, it is with this in mind that Spolsky theorised about the determinants of language policy. He offers a tripartite conceptualisation that has been frequently applied in language policy research, including in respect to Iceland (HilmarssonDunn and Kristinsson 2010; Kristinsson 2012). This frames language policy as comprising three distinct components (Spolsky 2007):

- Language management, which concerns how authorities intervene to regulate language with 'explicit and observable efforts by someone or some group that has or claims to have authority over the participants in the domain to modify their practices and beliefs' (Spolsky 2007: 4). For national language policy, the interest is likely confined to government instruments, such as legislation, policy and official programmes.

- Language beliefs or ideology, which concern what a community believes should happen with language. Language ideology is the manifestation of social, political and cultural principles into language beliefs (Woolard and Schieffelin 1994: 56) because 'there is a complex but non-arbitrary relationship between beliefs about language and beliefs about other things' (Cameron 2006: 151).

- Language practices, which concern how language is actually used in a language environment. The interest here is in grassroots societal norms that are 'regular and predictable' (Spolsky 2007: 3). This excludes language choices that are not habitual.

This tripartite language policy definition can accommodate the multitude of disciplinary perspectives that language policy research demands. It invites, for example, postmodernists to examine how national identity and sociolinguistic situations manifest in, and become contested through, language ideologies and practices. It may also accommodate the work of critical theorists examining the political, ideological and practical manifestations of inter-language power struggles and hegemony. Against Spolsky's national language policy theory, the tripartite definition is a framework for considering societal-level governance, beliefs and

\footnotetext{
${ }^{1}$ The Alpingi is the Icelandic parliament and was founded in $930 \mathrm{AD}$ (Alpingi n.d.).
}

\begin{tabular}{|l|lllll|}
\hline & Journal : Small-ext 10993 & Dispatch : $\mathbf{2 0 - 2 - 2 0 1 5}$ & Pages : 18 \\
& Article No. : $\mathbf{9 3 5 7}$ & $\square$ LE & & $\square$ & TYPESET \\
& MS Code : LPOL-537 & $\nabla$ & CP & $\square$ & DISK \\
\hline
\end{tabular}


practice. Having positioned and discussed Spolsky's national language policy theory and his definition of what language policy comprises, the paper now presents the findings of a systematic and critical analysis of each determinant in the Icelandic context.

\section{The impact of national ideology}

Icelandic-ness traditionally draws on two interrelated sources: Iceland's Golden Age literature in the thirteenth and fourteenth centuries (Helgason 2007) and nationalism against Denmark's colonial rule legitimised by Iceland's literary tradition and archaic language (Hálfdanarson 2003). Iceland's literary Golden Age narrated Scandinavian mythology and recalled Iceland's settlement and ancient kings (Sapir and Zuckermann 2008), with prominent works including the Book of Settlements, the Saga of Icelanders, Sagas of Kings, manuscripts of Skaldic poetry, and Snorri's renowned Edda poetry (Hilmarsson-Dunn and Kristinsson 2010). This Golden Age can be fairly tagged as Iceland's Great Tradition from Fishman's (1971) perspective because the literature became 'the basis for their national glory' (Sæmundsson 1835 cited in Hálfdanarson 2005: 57), and integral to Icelandic cultural life. Hilmarsson-Dunn and Kristinsson (2010) explain that the literature also captured wider Scandinavian attention: the monarchy and intellectuals of Denmark's reign of Iceland from 1262 revered the literature and decorated Icelandic as the proto-Scandinavian language. The literature even remains an important source of popular culture in Iceland today (Kristinsson 2000 cited in Holmarsdottir 2001).

Icelandic nationalism was for the most part founded by the nationalist Fjölnir periodicals between 1835 and 1847 (Ottosson 2002). An ideology to preserve the Golden Age language had endured, but Danish had become the language of prestige under Denmark's rule and the threat of Danish contaminating the ancient language was potent. Fjölnir radically sought to remove all Danish influences from Icelandic (Friðriksson 2009). Sigurðsson harnessed this groundwork to assert that Danish rule in Iceland was unequivocally unnatural, claiming that languages are markers of nationhood and Iceland's language was clearly unlike Denmark's (Friðriksson 2009). This linked Iceland's linguistic interests in no uncertain terms to nationalism. However, nationalism did not simply mean speaking a language other than Danish. Icelandic needed to be 'as close to its medieval form as possible' (Hálfdanarson 2005).

The importance of language in Icelandic-ness understandably led to a purist language ideology to preserve an unbroken link to the Golden Age (Friðriksson 2009). In fact, Icelandic-ness is considered so contingent on the pure form of Icelandic that the language is referred to as the egg of life (Kristmannsson 2004) because 'if the language changes, then the national compact will automatically dissolve' (Hálfdanarson 2005: 56). There are, however, speculations that the link between national ideology and language ideology may be weakening. Younger Icelanders, who generally support Iceland's economic and political internationalisation with Europe, are often perceived as less likely to attribute their Icelandicness to language and heritage (Friðriksson 2009).

\begin{tabular}{|l|llll|}
\hline & Journal : Small-ext 10993 & Dispatch : 20-2-2015 & Pages : 18 \\
Article No. : 9357 & $\square$ LE & $\square$ & TYPESET \\
& MS Code : LPOL-537 & $\square$ CP & $\square$ DISK \\
\hline
\end{tabular}


Thus, traditional Icelandic national ideology is clearly echoed in today's protectionist language interventions to preserve and promote Icelandic as the archaic Scandinavian language. The Árni Magnússon Institute of Icelandic Studies (AMIIS) increases 'awareness of the Icelandic language and its development and preservation in spoken and written form, and providing advice and instruction on an academic basis regarding linguistic matters' [Ministry of Education, Science and Culture (MESC) 2009: 20]. Importantly, preservation is about 'maintaining linguistic continuity from one generation to another with the aim of preserving the link between modern language and the earliest Icelandic literature' (Friðriksson 2009: 102) The AMIIS has often reinstated archaic morphological inflections where change occurred and publishes standards in handbooks (Árnason 2003). ${ }^{2}$ An enthusiasm for the Golden Age also seemingly underscores investments to promote Icelandic abroad. Iceland operates the free web-based Icelandic Online course in Icelandic language (AMIIS n.d.) and an enhanced tutor-assisted Icelandic Online Plus version (Icelandic Online 2012). The rationale presumably stems from the value of the Golden Age, rather than demand for Icelandic as a foreign language (FL) (MESC 2001).

It is less clear to what extent the ideology to foster an unbroken link to Old Norse has influenced actual language practice. Changes in languages are natural (Fromkin et al. 2009), and Iceland is no exception. Icelandic underwent drastic phonetic and phonological changes between the fourteenth and seventeenth centuries (Hilmarsson-Dunn 2003), making modern Icelandic substantially different in sound to Old Norse (Hilmarsson-Dunn and Kristinsson 2010). However, Svavarsdóttir (2008) explains that linguistic purism focussed primarily on the written language, not spoken Icelandic. The few changes that have occurred are morphological (Hilmarsson-Dunn 2003) and mostly associated with the case system (Svavarsdóttir 2008). ${ }^{3}$ The most discussed change is the so-called dative sickness: a tendency for accusative case objects to be used in the dative (Smith 1994: 675), but Friðriksson's (2009) study of broader case sicknesses amongst Icelandic children, found that only $13.13 \%$ of informants showed any signs of case sickness. Ultimately, the structure of Old Norse has persisted (Kvaran 2003) and Icelanders easily rely on modern Icelandic to read Golden Age literature (Kvaran 2004).

This poses the question whether the relative stability of Icelandic is indeed attributable to the workings of national ideology. Karlsson (2004) points to the surprising frequency of travel across the island throughout Icelandic history, especially for Alpingi meetings, family estates, intermarriages, to the few schools that existed, and for seasonal work. This maintained the form of Icelandic between communities. Hilmarsson-Dunn (2003) reflects on Milroy's (1992) view that tight social networks, as Iceland was, favour linguistic conservatism. However, Iceland's literary culture and ongoing engagement with the Golden Age throughout the

\footnotetext{
${ }^{2}$ For example, inflections on ia-stem nouns, such as laknir (doctor), had changed from Old Norse, but language management reinstated the archaic forms. For example, the archaic lakn-ar (plural nominative) replaced lakkn-irar, and the archaic laekn-is (single genitive) replaced lakk-irs (Árnason 2003).

${ }^{3}$ Icelandic has retained the four original cases of Old Norse: the nominative, accusative, dative and genitive, such as what existed in Old English, currently exists in German, but has been lost from Danish, Swedish and Norwegian (Hilmarsson-Dunn 2003: 11).
}

\begin{tabular}{|l|lllll|}
\hline & Journal : Small-ext 10993 & Dispatch : $\mathbf{2 0 - 2 - 2 0 1 5}$ & Pages : 18 \\
& Article No. : $\mathbf{9 3 5 7}$ & $\square$ LE & $\square$ & TYPESET \\
MS Code : LPOL-537 & $\square$ CP & $\square$ & DISK \\
\hline
\end{tabular}


centuries also helped to avoid language change (Hilmarsson-Dunn 2003), meaning language stability is most likely attributable to both Milroy's theory and Iceland's reverence for its Great Tradition. It is unclear, however, how much relative weight these factors held. Thus, Milroy's theory became less applicable by the midnineteenth century when societal networks began to transition but language stability continued. At that time, Icelandic nationalism, as a new aspect of national ideology, became a driving influence (Friðriksson 2009) because corpus planning, such as Fjölnir's, described purist language practices as anti-Danish and markers of Icelandic-ness.

\section{The impact of English as a global language}

English is no doubt a motivating force in Icelandic language policy. Iceland's response to English is dichotomised by the tension that May (2014) describes between the cosmopolitan and the local: Icelanders pursue the perceived global benefits of English language proficiency, but seek to counter its influence through protectionist policy in the interests of preserving their local language. Language acquisition planning has increasingly reflected a pragmatic interest in foreign language skills for international success (Hilmarsson-Dunn and Kristinsson 2010) and interests in English began shifting in the 1940s (Rasmussen 2002) when English became Europe's primary lingua franca (Cogo and Jenkins 2010). The curriculum now prescribes English as the first foreign language (MESC 2012) and by the end of formal schooling, students anticipate an advanced proficiency up to the $\mathrm{C} 1$ level on the Common European Framework of Reference for Languages (CEFRL) (Jeeves 2012). English also enjoys hearty ideological support in schools: MESC research of 23 teachers and 788 students found that learners and educators value English highly (Lefever 2006) and Jeeves' (2010) survey of 16 students across Iceland even found that English competence is linked to a youthful Icelandic sense of self in the international arena. It is broadly agreed that Icelanders are, in the main, highly proficient users of English, not in the least, for example, because Icelanders commonly undertake English-medium tertiary education (Arnbjörnsdóttir 2010).

The assumption that English is Iceland's preferred language in the international arena is indeed applied in practice (Kvaran 2010). This reflects specifically in the much-discussed trend of English as a global language (see Phillipson and SkutnabbKangas 1996) and as Europe's lingua franca (Cogo and Jenkins 2010; Cramer 2007; Kachru 1985). The dominance of English is, to a limited degree, challenged in formal intra-Scandinavian relations. The Nordic Language Declaration aims for Scandinavian dialogue in Scandinavian languages parallel to, but not replaced by, English (NCM 2006). On the basis of the assumed mutual-intelligibility of Danish, Norwegian and Swedish, Icelanders traditionally used Danish in intra-Scandinavian fora (Hilmarsson-Dunn and Kristinsson 2010). However, actual practice is more complicated: the assumed mutual-intelligibility is questioned by L2 speakers, and Scandinavian cooperation has also expanded to include the Baltic states (Hilmarsson-Dunn and Kristinsson 2010). Consequently, Scandinavian dialogue often resorts to English (Hilmarsson-Dunn 2006). 
Another primary, but related, focus of Icelandic language policy is the management of anglicisms (Sapir and Zuckermann 2008). The AMIIS, with the help of around 50 voluntary committees (Hilmarsson-Dunn and Kristinsson 2009), replaces anglicisms as they arise with native Icelandic neologisms (Holmarsdottir 2001; Kvaran 2004). The pervasive ideology that preserving Icelandic also amounts to avoiding loanwords means corpus planning is indeed 'widely supported, both officially and among the general public' (Svavarsdóttir 2008: 455). Graedler (2004) quantified these sentiments when she found that of all Scandinavians, Icelanders are the most exposed to English but also the most sceptical of it, with $63 \%$ agreeing neologisms are necessary. Icelandic's structural complexities help to filter out unacceptable anglicisms because loanwords are only feasible if they can comply with Icelandic phonology and morphology (Kvaran 2004). It is therefore often easier to create neologisms (Árnason 1999 cited in Friðriksson 2009). Also, Icelanders themselves seem generally loyal to corpus planning efforts, as it appears that the frequency of using a given loanword decreases after a neologism is promulgated, such as tölva (computer) which may have virtually replaced its preceding anglicism (Hilmarsson-Dunn and Kristinsson 2009).

\section{The impact of the sociolinguistic situation}

Iceland's contemporary sociolinguistic situation also informs the nation's language policy in so far that the government acknowledges linguistic diversity, but heralds the primacy of Icelandic and anticipates the linguistic assimilation of migrants. Immigration particularly accelerated in 1996 (Statistics Iceland 2009), and whereas in 1995 Iceland accepted 938 new migrants, 9,318 arrived in 2007 (Statistics Iceland 2012). Iceland now hosts around 25,000 immigrants, over 2,500 s-generation immigrants, and almost 14,000 Icelanders with a foreign-born parent. The largest groups are the Polish $(9,363)$ and Lithuanian $(1,589)$ communities (Statistics Iceland 2013). The arrival of Polish economic migrants is well-documented (see e.g. Tworek 2010), and both Poland's and Lithuania's recent accession to the European Economic Area (EEA) facilitates easier access to Iceland's labour market (EFTA 2012).

English is also flooding domestic language domains to the extent that it is often touted as Iceland's L2 (Arnbjörnsdóttir 2007). Businesses often favour bilingual cultures (Jónsdóttir 2011) especially because, as a small economy, corporate expansions are often international (Foreign Affairs 2008). Jónsdóttir's (2011) crosssector research found that $74.7 \%$ of working Icelanders use English daily, especially for reading documents and writing emails. Like elsewhere in Scandinavia and beyond, English is also bonded to tertiary education and academia (Holmarsdottir 2001). Professors of Icelandic-medium courses are even said to entertain requests to shift to English (Robert 2011) and the shift is exacerbated by Icelanders generally being willing and able to pursue English-medium studies (Arnbjörnsdóttir 2010). Media and popular culture, other than Golden Age literature, are predominantly in English and enjoy popularity (Hilmarsson-Dunn 2010). The pervasiveness of English in IT, including the use of English-language programming

\begin{tabular}{|l|lllll|}
\hline & Journal : Small-ext 10993 & Dispatch : $\mathbf{2 0 - 2 - 2 0 1 5}$ & Pages : 18 \\
& Article No. : $\mathbf{9 3 5 7}$ & $\square$ LE & & $\square$ & TYPESET \\
& MS Code : LPOL-537 & $\nabla$ & CP & $\square$ & DISK \\
\hline
\end{tabular}


despite some investments by the government in Icelandic software, prompts speculation that Icelandic will lose this domain entirely (Hilmarsson-Dunn 2006; Rögnvaldsson 2008). It is also possible that English competes with Icelandic as a lingua franca with immigrants, as Einarsdóttir (2011) found that out of eleven migrants, only four claimed to speak Icelandic, and a common impediment is that Icelanders willingly switch to English with immigrants. Pórarinsdóttir (2011 cited in Berman et al. 2011) identified that $40 \%$ of Poles view their residence in Iceland as temporary, meaning a motivation to acquire Icelandic may be minimal if migrants can rely on English.

Indeed, the recent advent of linguistic diversity means status planning only recently seemed relevant (Hilmarsson-Dunn and Kristinsson 2009; Kristinsson 2012). Icelandic was eventually legislated as the official language in 2011 (Act on the Status of the Icelandic Language and Icelandic Sign Language no. 61/2011, Article 1), seemingly in response to perceived threats to its status and to language tradition, as Kristinsson (2012) discusses. This legislation also confirmed the statutory role of the Icelandic Language Committee to advise and report on the status of Icelandic (Article 6). The Act built on the Íslenska Til Alls (Icelandic for Everything) policy of 2009 that aims to increase use of Icelandic in public domains (Hilmarsson-Dunn and Kristinsson 2010). Education legislation (The Compulsory School Act no. 91/2008, Article 16 and The Upper Secondary School Act no. 92/2008, Article 35) confirms Icelandic as the medium of instruction in schools (Hilmarsson-Dunn and Kristinsson 2010). Immigration and citizenship laws recognise linguistic diversity only by anticipating linguistic assimilation whereby permanent residence applicants must demonstrate completion of Icelandic language studies (Regulation on Foreigners no. 53/2003, Article 50). Citizenship applicants must pass an Icelandic language examination (Regulations on Icelandic Language Tests for Persons Applying for Icelandic citizenship no. 1129/2008, Article 1) at the A2 level on the CEFRL [European Commission Against Racism and Intolerance (ECRI) 2012]. The impact of these immigration and citizenship laws is probably limited because the largest migrant groups are from within the EEA and therefore generally have liberal access to residence and the Icelandic labour market without applying for residence or citizenship (Útlendingastofnun, n.d.). Nonetheless, these hegemonic laws intimate that Icelandic language management is motivated by the mosaic sociolinguistic reality.

How Iceland's new multilingual reality manifests in language ideology has undergone little investigation (Friðriksson 2009), but indications are that ideology is unlikely to celebrate linguistic diversity. Further research might reveal, for example, that Iceland presents with a predominantly monoglot ideology (Silverstein 1996), whereby the speech community is characterised by linguistic diversity but the community will 'pledge allegiance to a single norm' (Blommaert 2008: 11). Despite migrant languages and the role of English, language management described so far indeed ascribes allegiance to Icelandic. If such interventions honestly mirror public beliefs, then a monoglot ideology likely exists. Alternatively, ideology may simply exclude linguistic diversity from participating in a definition of contemporary Icelandic-ness, thereby excluding non-speakers from the perceived Icelandic linguistic community. For example, public discourse shows that migrant

\begin{tabular}{lllll} 
Journal : Small-ext 10993 & Dispatch : & $\mathbf{2 0 - 2 - 2 0 1 5}$ & \multicolumn{2}{l}{ Pages : 18 } \\
Article No. $: \mathbf{9 3 5 7}$ & $\square \quad$ LE & $\square$ & TYPESET \\
MS Code : $\quad$ LPOL-537 & $\square$ & CP & $\square$ & DISK \\
\hline
\end{tabular}


communities are marginalised and interactions with foreigners are often minimal, or sometimes even hostile, a matter which worries the ECRI (2011). This creates a chasm between Icelanders and others. Indeed, the term Icelander is reserved for 'those who speak Icelandic and share Iceland's history and culture' (Bragason 2001).

\section{The impact of an internationally growing interest in linguistic minority rights}

It would so far seem doubtful that linguistic minority rights have informed Iceland's language policy. The most notable achievement for language rights was the recognition of Icelandic Sign Language (ISL) in 2011 (Act on the Status of the Icelandic Language and Icelandic Sign Language no. 61/2011, Article 13) which affords Icelandic Sign Language (ISL) equal status with Icelandic. Affording ISL status was, however, ideologically innocuous because ISL does not threaten traditional Icelandic purism and homogeneity and instead attends to other human rights concerns.

Instead, Iceland's legal stance on minority languages is hegemonic. The 2011 legislation is silent on languages other than Icelandic and ISL, but constructs a right for non-Icelanders to acquire Icelandic (Act on the Status of the Icelandic Language and Icelandic Sign Language no. 61/2011, Article 2). However, even implementation of this can attract the attention of critical theorists: the nature of course materials, tuition costs, availability of classes, and lack of time amongst working migrants create barriers to accessing the right (MESC 2009 cited in Hilmarsson-Dunn and Kristinsson 2010). Icelandic L2 classes also allegedly ignore the needs of illiterate/ semi-literate learners, especially high-needs Asian learners. Indirect discrimination occurs in the job market where an immigrant does not command 'perfect' Icelandic, and social marginalisation often means immigrants have minimal opportunity to practise speaking Icelandic (Icelandic Human Rights Centre 2011). The language legislation of 2011 codified a right for non-Icelanders to access interpreters in courts of law (Act on the Status of the Icelandic Language and Icelandic Sign Language no. 61/2011, Article 8), but fell short of providing interpreters for mainstream social services. However, a right to a free interpreter does feature in health care, asylum, and deportation legislation (Act on the Rights of Patients no. 74/1997, Article 5 and Regulation on Foreigners no. 53/2003, Articles 57, 88, 89; MSA 2007). In practice, the accessibility of multilingual health care information is criticised (The Icelandic Cancer Society 2005) and medical professionals often use English with immigrants rather than engaging an interpreter (Hilmarsson-Dunn and Kristinsson 2010).

Instead, I argue that the current policy framework actually risks initiating language shift away from migrant languages. Minority language maintenance is constrained by legislation that stipulates Icelandic as the only acceptable medium of instruction in compulsory education. Schools are instead tasked to develop and deliver reception plans that ensure immigrant children learn Icelandic (The Compulsory School Act no. 91/2008, Article 16). Where possible, a minority language may be studied as a foreign language instead of a Nordic language (MSA 2007), however Statistics Iceland (2012) has not reported any students recently studying Polish or Lithuanian (the largest minorities). Secondly, as May (2006) would predict, the generally hegemonic bias of the policy framework, and the

\begin{tabular}{|l|llll|}
\hline & Journal : Small-ext 10993 & Dispatch : & $\mathbf{2 0 - 2 - 2 0 1 5}$ & Pages : 18 \\
Article No. : 9357 & $\square \quad$ LE & $\square$ & TYPESET \\
& MS Code : LPOL-537 & $\square \quad C P$ & $\square$ & DISK \\
\hline
\end{tabular}


ongoing marginalisation of migrants, creates pressure to abandon minority languages, especially in formal domains. Further research could investigate whether, and how, immigrants who settle in Iceland experience language shift in the long-term.

Spolsky's notion that governments are necessarily interested in attending to and affording positive language rights is, therefore, problematic. It seems, at least in the case of Iceland, that it turns a blind-eye to linguistic hegemony and assumes democratic and inclusive policy making. Indeed, nations with hegemonic cultural political agendas, such as for the purposes of unity, may be less likely to afford linguistic rights to minorities. Spolsky (2004) himself has referred to Oman, Saudi Arabia, Portugal and Turkey as examples of 'monolingual countries with marginalised minorities' (p. 139-142) which seemingly fall into a similar camp as Iceland. Réaume and Pinto's (2012) discussions are especially useful. To their theorising, non-rights-based approaches to managing language diversity especially emerge where diversity is seen as a threat rather than an opportunity (p. 39). In such cases, governments may engage the language rights question but decide to deny language rights on the basis of local socio-political interests than to grant them, and this is indeed evident in Iceland. Therefore, the question under Spolsky's framework of how language rights inform national language policies has assumed a positive interest in linguistic rights which is not a universally default position.

However, in the case of Iceland an interest in linguistic rights nonetheless informs language policy, but in a way that is self-reflexive and not as Spolsky envisaged. Rather than attending to domestic minorities, Icelandic policy and discourse frequently position the Icelandic language itself as an international relative minority 534 requiring protection. This paper has already described a recurring theme of encroaching language majorities and other perceived threats motivating Icelandic language management. However, Icelandic was most illustratively framed as a minority when the government mounted a battle against Microsoft which had refused to develop Icelandic-language software. Iceland viewed this as a disastrous imposition of supranational language policy on a minority (Holmarsdottir 2001). Academic

540 literature also tends to frame Icelandic as minoritised: for example, Holmarsdottir (2001) groups Iceland with minorities that 'suffer stigmatisation as a result of the removal of the language from areas of social, economic and political power' (p. 391), and Hilmarsson-Dunn (2006) proposes that 'Icelandic requires continued strong support from the state and a positive attitude from its citizens to prevent it succumbing to market pressures' (p. 309). This, however, is usefully contrasted with Svavarsdóttir's (2008) pragmatic argument that Icelandic, as the overwhelmingly predominant language of Icelanders with a standardised form and strong literary tradition, is undeniably a majority language. She argues that 'there is no obvious justification for this feeling of an external threat to the language in present times' (p. 455).

\section{Conclusion}

551 This paper has argued that, at present, only three of Spolsky's four forces drive 552 language policy in Iceland in the way Spolsky envisaged: national ideology, English

\begin{tabular}{|l|llll|}
\hline & Journal : Small-ext 10993 & Dispatch : $\mathbf{2 0 - 2 - 2 0 1 5}$ & Pages : 18 \\
Article No. : $\mathbf{9 3 5 7}$ & $\square \quad$ LE & $\square$ & TYPESET \\
& MS Code : LPOL-537 & $\square \quad C P$ & $\square$ & DISK \\
\hline
\end{tabular}


as a global language, and the sociolinguistic situation. National ideology, steeped in

554

555 a reverence for Iceland's Golden Age of literature and linguistically-inspired nationalism, fostered policy and practices of linguistic purism that have sheltered Icelandic from language change. Indeed, Icelandic today is by and large the language of Iceland's ancient forefathers. The rise of English as a global language has created both enthusiasm for language acquisition as well as protectionist language planning measures to counter its influence and safeguard Icelandic. Immigration and the emerging linguistic mosaic have engaged traditional Icelandic apprehensions about linguistic diversity and sparked hegemonic reactions that silence minority languages and confirm the primacy of Icelandic. Accordingly, an interest in the rights of linguistic minorities to develop and use their languages has not yet informed Iceland's current language policy. The hegemony of official policy and absence of minority language rights even risks initiating language shift within immigrant communities. The only interest in linguistic rights seems self-reflexive in that policy and discourse attend to the vulnerability of Icelandic as an international minority struggling in the global language ecology.

It therefore seems that Spolsky's theory does not account for non-rights based approaches to national language policy such as Iceland's. Whereas Spolsky envisaged increasingly sympathetic responses to minority groups, the Icelandic situation sooner sees domestic linguistic diversity as a threat. However, rather than removing an interest in linguistics rights as the fourth component of Spolsky's theory, I suggest its coverage be expanded: instead of this component seeing nations as necessarily adopting positive stances on minority rights, it could be seen as a political domain which nations are increasingly required to engage in some way, whether the results are permissive, silent towards, or restrictive for the minorities concerned. Although Iceland has not advanced linguistic rights for its minorities as Spolsky envisaged, it has nonetheless engaged that question: it chose to advance rights for itself on the international stage, but not for its own sizeable Polish and Lithuanian communities. As such, seeing this final factor as an area of engagement means it can account for various political responses to the notion of linguistic rights, or even apply this interest self-reflexively as Iceland has.

The activity of applying Spolsky's theory has also shown it is not positioned to trace the practical journeys and experiences of official language policy through its many layers, agents and process from the bureaucracy down to the individual. Even when using Spolsky's own tripartite language policy definition to include language beliefs and language practices as policy, the theory's focus at the national level means it misses the locally contextualised community-level contestations, appropriations and negotiations that impact on the actual realisation of policy. However, I hasten to add that while postmodernist, ethnographic and multi-layered approaches to language policy that can conduct such research are important, it is also still very valuable to examine how and why governments arrive at particular language policy solutions. Indeed, this is the genesis of change that can ultimately background and even necessitate community-level research vis-à-vis national policy directives. Rather than seeing Spolsky's theory as too focussed on the macro at the expense of the micro, I see his theory as only better equipping scholarship to contextualise any grassroots language policy situation or discourse that is positioned against or

\begin{tabular}{|l|llll|}
\hline & Journal : Small-ext 10993 & Dispatch : & $\mathbf{2 0 - 2 - 2 0 1 5}$ & Pages : 18 \\
& Article No. : 9357 & $\square \quad$ LE & $\square$ & TYPESET \\
& MS Code : LPOL-537 & $\square \quad C P$ & $\square$ & DISK \\
\hline
\end{tabular}


informed by state policy. The case of Iceland is proof: the theory has especially 600 helped decipher how and why Icelandic society and its government, armed with 601 national ideology and centuries of linguistic apprehensions arrived at their 602 contemporary state language policies. For this reason, I also suggest that Spolsky's 603 national language policy theory may be more successfully applied to explain 604 national-level language management, to the exclusion of language beliefs and 605 language practices which otherwise constitute his full conceptualisation of 606 language policy but manifest differently in the many layers of the language policy 607 onion. Ultimately, for the purpose of Iceland as a test case, it is now the task of other 608 researchers from other theoretical traditions to examine the lived experiences of 609 Iceland's official language policies.

Acknowledgments This work was partly supported by the Research Council of Norway through its Centres of Excellence funding scheme, Project Number 223265.

\section{References}

614

615

616

617

618

619

620

621

622

623

624

625

626

627

628

629

630

631

632

633

634

635

636

637

638

639

640

641

642

643

644

645

646

647

Affairs, F. (2008). Icelandic business is a global business. Foreign Affairs, 87(4), 13.

Alpingi. (n.d.). Establishment of the Alpingi. http://www.Alpingi.is/kynningarefni/index_en.html. Accessed 11 Nov 2012.

Árnason, K. (2003). Icelandic. In A. Deumert \& W. Vandenbusche (Eds.), Germanic standardizations (pp. 245-280). Amsterdam; Philadelphia: John Benjamins Publishing Company.

Arnbjörnsdóttir, B. (2007). English in Iceland: Second language, foreign language, or neither? In B. Arnbjörnsdóttir \& H. Ingvarsdóttir (Eds.), Teaching and learning English in Iceland (pp. 51-78). Reykjavík: Haskolautgafan.

Arnbjörnsdóttir, B. (2010). Coping with English at University: Students beliefs. http://netla.hi.is/ menntakvika2010/008.pdf. Accessed 9 Sept 2012.

Arnbjörnsdóttir, B. (2011). Exposure to English in Iceland: A quantitative and qualitative study. http:// netla.hi.is/menntakvika2011/004.pdf. Accessed 9 Sept 2012.

Árni Magnússon Institute for Icelandic Studies (AMIIS). (n.d.). Courses in Icelandic. http://www. arnastofnun.is/page/a_inter_courses_in_icelandic. Accessed 9 Sept 2012.

Berman, R., Lefever, S. \& Woźniczka, A.K. (2011). Attitudes towards languages and cultures of young polish adolescents in Iceland. http://skemman.is/stream/get/1946/12394/30759/1/robert.pdf. Accessed 10 Aug 2012.

Blommaert, J. (2008). Language, asylum, and the national order. http://www.kcl.ac.uk/innovation/groups/ 1dc/publications/workingpapers/50.pdf. Accessed 26 July 2012.

Bragason, U. (2001). Attitudes to the Icelandic language. http://arnastofnun.is/page/attitudes_ub. Accessed 1 July 2012.

Cameron, D. (2006). Ideology and language. Journal of Political Ideologies, 11(2), 141-152.

Cogo, A., \& Jenkins, J. (2010). English as a Lingua Franca in Europe. European Journal of Language Policy, 2(2), 271-294.

Cramer, J. (2007). English in the expanding European Union. Revisiting berns' evaluation of "the twelve". http://ling.uta.edu. Accessed 9 July 2012.

EFTA. (2012). EEA agreement. http://www.efta.int/eea/eeaagreement.aspx. Accessed 15 July 2012.

Einarsdóttir, K.A. (2011). Young unemployed migrants in Iceland: Opportunities on the labour market and situations after the economic collapse with regard to work, social and financial aspects. http:// skemman.is/stream/get/1946/7978/20802/1/MA_ritgerd_lokaeintak_til_prentunar_og_i_skemmu. pdf. Accessed 11 Aug 2012.

European Commission Against Racism and Intolerance (ECRI). (2011). ECRI report on Iceland. http:// www.coe.int/t/dghl/monitoring/ecri/country-bycountry/iceland/ISL-CbC-IV-2012-001-ENG.pdf. Accessed 21 Sept 2012.

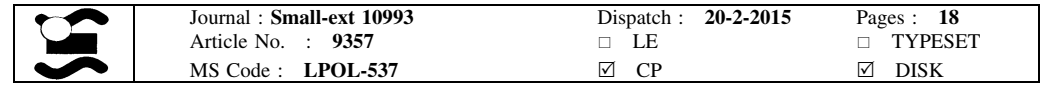


Fishman, J. (1971). National languages and languages of wider communication in the developing nations. In W. H. Whiteley (Ed.), Language use and social change. Problems of multilingualism with special reference to Eastern Africa (pp. 27-56). London: Oxford University Press.

Friðriksson, F. (2009). Language change vs. stability in conservative language communities: A case study of Icelandic. Saarbrücken: VDM Verlag.

Fromkin, V., Rodman, R., Hyams, N., Collins, P., Amberber, M., \& Harvey, M. (2009). An introduction to language. Australia: Cengage Learning.

Graedler, A. (2004). Modern Loanwords in the Nordic Countries. Presentation of a project. Nordic Journal of English Studies, 3(2), 5-21.

Hálfdanarson, G. (2003). Language, ethnicity and nationalism: The case of Iceland. In G. Hálfdanarson (Ed.), Racial discrimination and ethnicity in European history (pp. 193-203). Pisa: Edizioni Plus.

Hálfdanarson, G. (2005). From linguistic patriotism to cultural nationalism: Language and identity in Iceland. In A. K. Isaacs (Ed.), Languages and identities in historical perspective (pp. 55-67). Pisa: Edizioni Plus.

Helgason, J. K. (2007). The Mystery of Vínarterta. In search of an Icelandic ethnic identity. Scandinavian-Canadian Studies, 17, 36-52.

Hilmarsson-Dunn, A. (2003). Icelandic: Linguistic maintenance or change? The role of English. Centre for Language in Education: Occasional Paper no 66. University of Southampton.

Hilmarsson-Dunn, A. (2006). Protectionist language policies in the face of the forces of English: The case of Iceland. Language Policy, 5, 293-312.

Hilmarsson-Dunn, A. (2009). The impact of English on language education policy in Iceland. European Journal of Language Policy, 1(1), 39-59.

Hilmarsson-Dunn, A. (2010). the impact of global English on language policy for the media: The case of Iceland. In M. Georgieva \& A. James (Eds.), Globalization in English studies (pp. 2-22). Cambridge: Cambridge Scholars Publishing.

Hilmarsson-Dunn, A., \& Kristinsson, A. (2009). Iceland's language technology: Policy versus practice. Current Issues in Language Planning, 10(4), 361-376.

Hilmarsson-Dunn, A., \& Kristinsson, A. (2010). The language situation in Iceland. Current Issues in Language Planning, 11(3), 207-276.

Holmarsdottir, H. (2001). Icelandic: A lesser-used language in the global community. International Review of Education, 47(3-4), 379-394.

Icelandic Human Rights Centre (IHRC). (2011). Submission to the universal periodic review of Iceland: 12th UPR Session October 2011. http://lib.ohchr.org/HRBodies/UPR/Documents/session12/IS/JS1JointSubmission1-eng.pdf. Accessed 18 Sept 2012.

Icelandic Online (2012). Icelandic online PLUS. http://icelandiconline.is/info/plus.php. Accessed 18 July 2012.

Jeeves, A. (2010). English at secondary school: Perceptions of relevance. Málfríður, 27(2), 4-9.

Jeeves, A. (2012). Learning to write correct English was the most useful thing: Young Icelanders' perceptions of writing in English. Paper presented at the Conference of the Association of Teachers of English in Iceland, Reykjavík, Iceland.

Johnson, D. (2013). Language policy. Basingstoke: Palgrave Macmillan.

Johnson, D., \& Ricento, T. (2013). Conceptual and theoretical perspectives in language planning and policy: Situating the ethnography of language policy. International Journal of the Sociology of Language, 219, 7-21.

Jónsdóttir, H. (2011). To what extent do native and non-native speakers believe that their english proficiency meets their daily communication needs within the business environment? Málfríður, 27(2), 20-23.

Jørgensen, J. N. (2008). Polylingual languaging around and among children and adolescents. International Journal of Multilingualism, 5(3), 161-176.

Kachru, B. (1985). Standards, codification and sociolinguistic realism: The English language in the outer circle. In R. Quirk \& H. G. Widdowson (Eds.), English in the world: Teaching and learning the language and literature (pp. 11-30). Cambridge: Cambridge University Press.

Karlsson, S. (2004). The Icelandic language. Exeter: Short Run Press.

Kristinsson, A. P. (2012). Language management agencies counteracting perceived threats to tradition. Language Policy, 11, 343-356.

Kristmannsson, G. (2004). Iceland's “Egg of Life” and the modern media. Meta: Translators' Journal, $49(1), 59-66$.

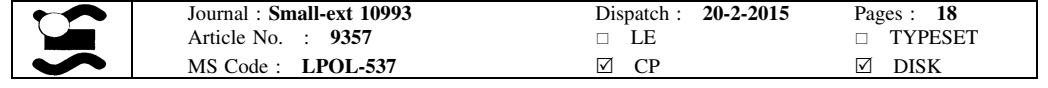


Kvaran, G. (2003). Icelandic language policy in past, present and future. Paper presented at the European Federation of National Institutions for Language Conference, Stockholm, Sweden.

Kvaran, G. (2004). English influence on the Icelandic lexicon. Nordic Journal of English Studies, 3(2), $143-152$.

Kvaran, G. (2010). The Icelandic language in business and commerce in Iceland. In G. Stickel (Ed.), Language use in business and commerce in Europe (pp. 117-122). Frankfurt: Peter Lang GmbH.

Lefever, S. (2006). English language teaching in Icelandic compulsory schools. Málfríður, 22(2), 9-12.

May, S. (2006). Language policy and minority rights. In T. Ricento (Ed.), An introduction to language policy theory and method (pp. 255-272). Malden: Blackwell.

May, S. (2014). Justifying educational language rights. Review of Research in Education, 38, 215-241.

May, S., \& Hill, R. (2005). Māori-medium education: Current issues and challenges. International Journal of Bilingual Education and Bilingualism, 8(5), 377-403.

Menken, K., \& García, O. (2010). Negotiating language policies in schools: Educators as policymakers. New York: Routledge.

Milroy, J. (1992). Linguistic variation and change. Oxford: Blackwell.

Ministry of Education, Science and Culture (MESC). (2001). Icelandic: At once ancient and modern. http://www.iceland.is/media/Utgafa/Icelandic.pdf. Accessed 29 June 2012.

Ministry of Education, Science and Culture (MESC). (2009). Culture. http://eng.menntamalaraduneyti.is/ media/MRN-PDF-Althjodlegt/culture2008.pdf Accessed 17 Nov 2012.

Ministry of Education, Science and Culture (MESC). (2012). The Icelandic national curriculum guide for compulsory school: General section: 2012. http://brunnur.stjr.is/mrn/Utgafuskra/utgafa.nsf/ RSSPage. $x$ sp?documentId=C590D16CBC8439C500257A240030AE7F\&action=openDocument. Accessed 17 Nov 2012.

Ministry of Social Affairs (MSA). (2007). Government policy on the integration of immigrants. http:// eng.velferdarraduneyti.is/media/acrobat-enskar_sidur/stefna_integration_of_immigrants.pdf. Accessed 17 Aug 2012.

Nordic Council of Ministers (NCM). (2006). Declaration on a Nordic language policy. http://www. norden.org/en/publications/publikationer/2007-746/at_download/publicationfile. Accessed 4-8 Dec 2012.

Ottosson, K. (2002). Language cultivation and language planning IV: Iceland. In B. Oskar, K. Braunmüller, E. H. Jahr, A. Karker, H. Naumann, \& U. Teleman (Eds.), The Nordic languages: An international handbook of the history of the north Germanic languages (pp. 1997-2007). Berlin, New York: Walter de Gruyte.

Pennycook, A. (2002). Mother tongues, governmentality, and protectionism. International Journal of the Sociology of Language, 154, 11-28.

Pennycook, A. (2006). Postmodernism in language policy. In T. Ricento (Ed.), An introduction to language policy theory and method (pp. 60-76). Malden: Blackwell.

Pennycook, A. (2013). Language policies, language ideologies and local language practices. In L. Wee, R. Goh, \& L. Lim (Eds.), The politics of English: South Asia, Southeast Asia and the Asia pacific (pp. 1-18). Amsterdam: John Benjamins.

Phillipson, R. (2003). English-only Europe? Challenging language policy. London: Routledge.

Phillipson, R., \& Skutnabb-Kangas, T. (1996). English only worldwide or language ecology? TESOL Quarterly, 30(3), 429-452.

Rasmussen, P. (2002). Globalisation. Málfríður, 18(1), 27-31.

Réaume, D., \& Pinto, M. (2012). Philosophy of language policy. In B. Spolsky (Ed.), The Cambridge handbook of language policy (pp. 37-58). Cambridge: Cambridge University Press.

Ricento, T. (2006). Language policy: theory and practice an introduction. In T. Ricento (Ed.), An introduction to language policy: Theory and method (pp. 10-23). Malden: Blackwell.

Robert, Z. (2011). Language of instruction. Iceland review. http://www.icelandreview.com/iceland review/daily_life/Language_of_Instruction_\%28ZR\%29_0_383254.news.aspx. Accessed 7 Dec 2012.

Rögnvaldsson, E. (2008). Iceland language technology 10 years later. Collaboration: Interoperability between people in the creation of language resources for less-resourced languages. Paper presented at the SALTMIL workshop, LREC 2008, Marrakech, Morocco. http://notendur.hi.is/eirikur/english. htm. Accessed 11 Aug 2012.

Sapir, Y., \& Zuckermann, G. (2008). Icelandic Phonosemantic Matching. In J. Rosenhouse \& R. Kowner (Eds.), Globally speaking: Motives for adopting english vocabulary in other languages (pp. 19-44). Clevedon: Multilingual Matters.

\begin{tabular}{|l|llll|}
\hline & Journal : Small-ext 10993 & Dispatch : $\mathbf{2 0 - 2 - 2 0 1 5}$ & Pages : 18 \\
Article No. : 9357 & $\square$ LE & $\square$ & TYPESET \\
& MS Code : LPOL-537 & $\square$ CP & $\square$ DISK \\
\hline
\end{tabular}


Schiffman, H. (2006). Language policy and linguistic culture. In T. Ricento (Ed.), An introduction to language policy theory and method (pp. 111-125). Malden: Blackwell.

Shohamy, E. (2006). Language policy: Hidden agendas and new approaches. Abingdon: Routledge.

Smith, H. (1994). "Dative Sickness" in germanic. Natural Language and Linguistic Theory, 12(4), 675-736.

Spolsky, B. (2004). Language policy. Cambridge: Cambridge University Press.

Spolsky, B. (2005). Language Policy. In J. Cohen, K. T. McAlister, K. Rolstad, \& J. MacSwan (Eds.), ISB4: Proceedings of the 4th international symposium on bilingualism (pp. 2152-2164). Somerville, MA: Cascadilla Press.

Spolsky, B. (2007). Towards a theory of language policy. Working Papers in Educational Linguistics, 22(1), 1-14.

Spolsky, B. (2009). Language management. Cambridge: Cambridge University Press.

Spolsky, B., \& Shohamy, E. (2000). Language practice, language ideology and language policy. In R. D. Lambert \& E. Shohamy (Eds.), Language policy and pedagogy essays in honor of A. Ronald Watson (pp. 1-42). Amsterdam, Philadelphia: John Benjamins Publishing Company.

Statistics Iceland (SI). (2009). Immigrants and persons with foreign background 1996-2008. http://www. statice.is/lisalib/getfile.aspx?ItemID=9077. Accessed19 Sept 2012.

Statistics Iceland (SI). (2012). Key figures. http://www.statice.is/Pages/1390. Accessed 19 Sept 2012.

Statistics Iceland (SI). (2013). Population by origin and citizenship. http://www.statice.is/Statistics/ Population/Citizenship-and-country-of-birth. Accessed 2 Oct 2014.

Svavarsdóttir, A. (2008). Icelandic. In U. Ammon \& H. Haarman (Eds.), Sprachen des Europäischen Westens/Western European Languages I (pp. 441-457). Klagenfurt: Wieser Verlag.

The Icelandic Cancer Society. (2005). Preventing cancer across cultures. Paper presented at the NCU Conference, Malmö, Sweden.

Tworek, K. (2010). Motives of migration and types of migration: The case of polish immigrants in Iceland. http://migracje.civitas.edu.pl/index.php/en/motives-of-migration-and-types-ofmigrationthe-case-of-polish-immigrants-in-iceland. Accessed 2 Dec 2012.

Útlendingastofnun. (n.d.). Who does not need a residence permit after a certain period. http://www.utl.is/ index.php?option=com_content\&view=article\&id=100\&Itemid=102\&lang=en. Accessed 1 Dec 2012.

Whiteley, P. (2003). Do "language rights" serve indigenous interests? Some Hopi and other queries. American Anthropologist, 105(4), 712-722.

Woolard, K., \& Schieffelin, B. (1994). Language ideology. Annual Review of Anthropology, 23, 55-82.

Ytsma, J. (2000). Trilingual primary education in Friesland. In J. Cenoz \& U. Jessner (Eds.), English in Europe: The acquisition of a third language (pp. 222-235). Clevedon: Multilingual Matters.

Zavala, V. (2014). An ancestral language to speak with the "other": Closing down ideological spaces of a language policy in the Peruvian Andes. Language Policy, 13(1), 1-20.

Nathan John Albury is a Ph.D. researcher at the Center for Multilingualism in Society across the Lifespan at the University of Oslo with interests in language policy and planning, language attitudes and ideology, and Scandinavian approaches language management. He holds an M.A. (Linguistics) from the University of New England in Australia.

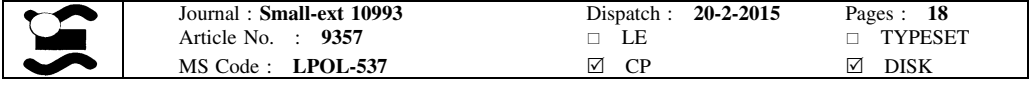

